\title{
ARBUSCURAL MYCORRHIZAL FUNGI INCREASED EARLY GROWTH OF GAHARU WOOD OF Aquilaria malaccensis and A. crasna UNDER GREENHOUSE CONDITIONS
}

\author{
Maman Turjaman, Erdy Santoso and Yana Sumarna ${ }^{1}$
}

\begin{abstract}
Gaharu wood stand has an important source of profits to the forest community in South and Southeast Asia tropical forest countries, but Aquilaria species have reduced in number and turn out to be endangered due to overexploitation. Today, the planting stocks of Aquilaria species are not sufficient to sustain the yield of gaharu wood and promote forest conservation. The objective of this study was to determine the effect of five arbuscular mycorrhizal (AM) fungi: Entrophospora sp., Gigaspora decipiens, Glomus clarum, Glomus sp. ZEA, and Glomus sp. ACA, on the early growth of Aquilaria malaccensis and $A$. crasna under greenhouse conditions. The seedlings of Aquilaria spp. were inoculated with Entrophospora sp., Gi. decipiens, Glomus clarum, Glomus sp. ZEA, Glomus sp. ACA and uninoculated (control) under greenhouse conditions. Then, percentage AM colonization, plant growth, survival rate and nitrogen $(\mathrm{N})$ and phosphorus $(\mathrm{P})$ content and mycorrhizal dependence (MD) were measured. The percentage AM colonization of $A$. malaccensis and A. crasna ranged from 83 to $97 \%$ and from 63 to $78 \%$, respectively. Colonization by five AM fungi increased plant height, diameter, and shoot and root dry weights. $\mathrm{N}$ and $\mathrm{P}$ content of the seedlings were also increased by AM colonization. Survival rates were higher in the AM-colonized seedlings at 180 days after transplantation than those in the control seedlings. The MD of Aquilaria species was higher than $55 \%$. The results suggested that AM fungi can be inoculated to Aquilaria species under nursery conditions to obtain vigorous seedlings, and the field experiment is underway to clarify the role of AM fungi under field conditions.
\end{abstract}

Keywords : AM fungi, tropical forest, gaharu wood, Aquilaria species, reforestation

\section{INTRODUCTION}

A tropical tree genus which currently has been an international attention focus is Aquilaria (Soehartono and Newton, 2001a). This genus is the main source of gaharu wood, a fragrant resinous wood, which rank among the most highly valuable non-timber products harvested from tropical forests. Gaharu wood is used in the manufacture of perfume, incense, traditional medicine, and other commercial products by Moslems and Asian buddhists. Aquilaria species are commonly found in primary and secondary lowland forests of Kalimantan, Sumatra, Sulawesi, Moluccas, West Papua, Papua New Guinea, Vietnam, India, Bangladesh, Bhutan, Myanmar, China, Cambodia, Thailand, Malaysia, Singapore, and the Philippines. Due to the high value of gaharu wood, Aquilaria has been severely overharvested throughout Asia during the last 20 years (Paoli et al., 2001). The species was

\footnotetext{
${ }^{1}$ Forest and Nature Conservation Research and Development Center, Bogor
} 
placed on appendix II of the Convention on the International Trade in Endangered Species (CITES) and considered to be threatened according to the IUCN Red List (CITES, 2005). Nevertheless, many Aquilaria spp. remain fallow, making it difficult not only to measure the protection status of Aquilaria spp., but also to sustain producing gaharu wood.

Many tropical soils are nutrient deficient or have substantial constraints to plant growth (Haselwandter and Bowen, 1996). Many of the soils, particularly in the tropical forests are very fragile, rapidly depleting their meagre soil resources on cultivation and becoming prone to wind or water erosion. It is required to improve the productivity of tropical forest lands and to enhance the commercial value of pulp, timber and non timber forest products. The fast production of high quality seedlings in nurseries is a vital stage for replenishing degraded tropical forest lands. Indigenous tree species, such as Aquilaria species, often grow slowly in the early growth stage compared with such fast growing species as Paraserianthes falcataria, Leucaena leucocephala, Acacia mangium, and Calliandra calothyrsus.

It has been reported that arbuscular mycorrhizal (AM) fungi increased growth of

some tropical trees. AM fungi increased seedling growth of Dicorynia guianensis (Caesalpiniaceae) from a tropical rain forest in French Guiana under nursery conditions (Béreau et al., 2000). Muthukumar et al. (2001) reported that the inoculation of Azadirachta indica (Meliaceae) with AM fungi improved plant growth compared with that of control seedlings. The AM fungi improved growth of the Brazilian pine Araucaria angustifolia (Araucariaceae) (Zandavalli et al., 2004). There are no reports on the improved growth of Thymelaeaceae tree species following AM fungal inoculation. Tawaraya et al. (2003) found the natural AM colonization of Gonystylus bancanus (Thymelaeaceae) in the peat swamp forests of Kalimantan. However, no information is available regarding the effect of AM fungi on the early growth of Aquilaria species. The objective of this study was to determine the effect of five AM fungi, Entrophospora sp. Ames and Scheneider, Gigaspora decipiens Hall and Abbott, Glomus clarum Nicholson and Schenk, Glomus sp. ZEA Tulasne and Tulasne and Glomus sp. ACA Tulasne and Tulasne, on the early growth of gaharu wood species $A$. malaccensis Lamk, and Aquilaria crasna Pierre ex Lecomte under greenhouse conditions.

\section{MATERIALS AND METHODS}

Seeds of Aquilaria malaccensis (provenance Bangka) were collected from a lowland forest in Bangka island and seeds of $A$. crasna (provenance Bogor) were collected from a forest of Salak mountain in Bogor, West Java. The seeds were soaked in water for about 2 hours and then surface-sterilized by shaking in $5 \% \mathrm{NaClO}$ for $5 \mathrm{~min}$. They were thoroughly rinsed twice in sterile distilled water. The seeds were sown in a plastic flat contained autoclavesterilized zeolite and grown under a 55\% shading intensity net to control solar radiation because these species require shady conditions. The seeds of Aquilaria species were allowed to germinate for 21 days after sowing. Ultisol was collected from Haurbentes Experimental Forest, Jasinga, West Java and stored in a greenhouse. The soil was passed through a $5 \mathrm{~mm}$ sieve and then mixed with river sand $(3: 1, \mathrm{v} / \mathrm{v})$ to improve drainage. The $\mathrm{pH}\left(\mathrm{H}_{2} \mathrm{O}\right)$ of the mixed soil was 4.7, available $\mathrm{P}$ (Bray-1) was $0.17 \mathrm{mg} \mathrm{kg}^{-1}$ and total $\mathrm{N}$ (Kjeldahl) was $0.17 \%$. The mixed soil was sterilized at $121^{\circ} \mathrm{C}$ for 30 minutes. Arbuscular mycorrhizal (AM) fungi of Entrophospora sp, Gi. decipiens, G. clarum, Glomus sp. ZEA and Glomus sp. ACA were isolated 
from peat soil of Kalampangan, Palangkaraya, Central Kalimantan, by trap culture. The pot cultures began as single spore cultures. They were propagated in pot cultures of Pueraria javanica. Plastic pots were filled with $175 \mathrm{~g}$ of sterilized zeolite and $5 \mathrm{~g}$ of AM fungal inoculum in the planting hole. Then, two of 6-day-old P. javanica seedlings were transplanted into the pots and placed under natural light greenhouse conditions with no temperature and humidity control. After 90 days in that condition, spores, external hyphae and colonized roots of Entrophospora sp, Gi. decipiens, G. clarum, Glomus sp. ZEA and Glomus sp. ACA were observed in the zeolite. Polyethylene pots (size 15 x $10 \mathrm{~cm}$ ) were filled with $500 \mathrm{~g}$ of sterilized mixed soil. AM inoculation was achieved by placing $5 \mathrm{~g}$ of AM inoculum of each species 1-3 cm under seedling. One 21-day-old A. malaccensis or $A$. crasna seedling was transplanted into the pots. Seedlings were watered daily with tap water to field capacity. Weed and pest controls were carried out manually. The seedlings were grown for 180 days in a greenhouse of the Forest and Nature Conservation Research and Development Center (FNCRDC), Bogor, West Java.

The experiment consisted of six treatments of $A$. malaccensis and $A$. crasna seedlings : (a) control (no inoculum); (b) Entrophospora sp.; (c) Gi. decipiens; (d) G. clarum; and (e) Glomus sp. ZEA; (f) Glomus sp. ACA. Each treatment was replicated five times. After harvest, shoots and roots were separated. They were oven-dried at $70^{\circ} \mathrm{C}$ for $72 \mathrm{~h}$ before weighing. Ground shoots were digested with $\mathrm{H}_{2} \mathrm{SO}_{4}$ and $\mathrm{H}_{2} \mathrm{O}_{2}$ solution $(3: 1, \mathrm{v} / \mathrm{v})$. Nitrogen $(\mathrm{N})$ and phosphorus (P) contents in the digested solution were determined by the semi-micro Kjeldahl method and molybdovanado-phosphoric acid method (Olsen and Sommers, 1982) respectively. An additional 30 seedlings each of $A$. malaccensis and A. crasna with Entrophospora sp., Gi. decipiens, G. clarum, Glomus sp. ZEA, Glomus sp. ACA or uninoculated were grown under the same conditions as those of the seedlings in the above experiment as controls. Numbers of viable seedlings were counted 180 days after transplanting. Survival rate was calculated as follows:

Survival rate $(\%)=($ number of viable seedlings / number of initial seedlings 30$) \times 100$

The roots were cleared in $100 \mathrm{~g} \mathrm{l}^{-1} \mathrm{KOH}$ for $1 \mathrm{~h}$, acidified with diluted $\mathrm{HCl}$ and stained with $500 \mathrm{mg} \mathrm{l}^{-1}$ tryphan blue in lactoglycerol (Brundrett et al., 1996). The roots were then destained in $50 \%$ glycerol. 1 -cm segments were viewed under a compound microscope at x200 magnification. The percentage root length colonized by AM fungi was estimated by scoring the presence or absence of AM fungal structures (McGonigle et al., 1990). Mycorrhizal dependency was calculated according to Plenchette et al. (1983): MD (\%) = (dry weight of mycorrhizal plant-dry weight of non mycorrhizal plant) / (dry weight of mycorrhizal plant) $x$ 100. Data were statistically analyzed using the analysis of variance (ANOVA) with the statistical software StatView 5.0 (Abacus Concepts). Comparison of means was done using the least significant difference (LSD) method and showed significant differences at $5 \%$ probability level. Interaction between nutrient content $(\mathrm{N}$ and $\mathrm{P})$ and shoot growth were tested with a linear regression (fitted line plot) and determined correlation coefficients. 


\section{RESULTS AND DISCUSSION}

\section{A. AM Colonization and Shoot Nutrient Concentrations}

A. crasna roots were more highly colonized by Entrophospora sp., Gi. decipiens, G. clarum, Glomus sp. ZEA, and Glomus sp. ACA than roots of $A$. malaccensis at 6 months after transplantation under greenhouse conditions (Table 1). There was significant in percentage colonization among treatments, except Glomus sp. ACA in weight, steam diameter and $G$. clarum in shoot DW and root DW. The control seedlings of both Aquilaria species were colonized by indigenous AM fungi.

Table 1. Arbuscural mycorrhizal (AM) colonization, plant growth and survival rates of $A$. malaccensis and $A$. crasna inoculated with or without AM fungi under greenhouse conditions

\begin{tabular}{|c|c|c|c|c|c|c|c|c|}
\hline \multirow[t]{2}{*}{ Treatment } & \multirow{2}{*}{$\begin{array}{c}\text { AM } \\
\text { coloni zation } \\
(\%)\end{array}$} & \multirow{2}{*}{$\begin{array}{l}\text { Height } \\
(\mathrm{cm})\end{array}$} & \multirow{2}{*}{$\begin{array}{c}\text { Stem } \\
\text { diameter } \\
(\mathrm{mm})\end{array}$} & \multicolumn{2}{|c|}{ Fresh weight (FW) } & \multicolumn{2}{|c|}{ Dry weight (DW) } & \multirow{2}{*}{$\begin{array}{c}\text { Surviva } \\
\text { rates } \\
(\%)\end{array}$} \\
\hline & & & & $\begin{array}{c}\text { Shoot } \\
\text { FW (g) }\end{array}$ & $\begin{array}{c}\text { Root } \\
\text { FW (g) }\end{array}$ & $\begin{array}{c}\text { Shoot } \\
\text { DW (g) }\end{array}$ & $\begin{array}{c}\text { Root } \\
\text { DW (g) }\end{array}$ & \\
\hline \multicolumn{9}{|l|}{ A. malaccensis } \\
\hline Control & $1 \mathrm{a}$ & $16.43 \mathrm{a}$ & $2.28 \mathrm{a}$ & $1.46 \mathrm{a}$ & $0.52 \mathrm{a}$ & $0.41 \mathrm{a}$ & $0.18 \mathrm{a}$ & 73 \\
\hline Entrosphora sp. & $97 \mathrm{~b}$ & $25.97 \mathrm{c}$ & $3.88 \mathrm{c}$ & $4.68 \mathrm{c}$ & $2.24 \mathrm{c}$ & $1.44 \mathrm{c}$ & $0.48 \mathrm{c}$ & 100 \\
\hline Gigaspora decipiens & $88 \mathrm{~b}$ & $21.91 \mathrm{~b}$ & $3.02 \mathrm{~b}$ & $2.92 \mathrm{~b}$ & $1.20 \mathrm{~b}$ & $0.88 \mathrm{~b}$ & $0.27 \mathrm{~b}$ & 100 \\
\hline Glomus clarum & $83 \mathrm{~b}$ & $19.96 \mathrm{~b}$ & $2.94 \mathrm{~b}$ & $2.90 \mathrm{~b}$ & $1.28 \mathrm{~b}$ & $1.95 \mathrm{c}$ & $0.78 \mathrm{c}$ & 97 \\
\hline Glomus sp. ZEA & $84 \mathrm{~b}$ & $22.33 \mathrm{~b}$ & $3.26 \mathrm{~b}$ & $2.62 \mathrm{~b}$ & $1.38 \mathrm{~b}$ & $0.79 \mathrm{~b}$ & $0.27 \mathrm{~b}$ & 90 \\
\hline Glomus sp. ACA & $86 \mathrm{~b}$ & $21.30 \mathrm{~b}$ & $3.12 \mathrm{~b}$ & $2.74 \mathrm{~b}$ & $1.22 \mathrm{~b}$ & $0.89 \mathrm{~b}$ & $0.26 \mathrm{~b}$ & 93 \\
\hline \multicolumn{9}{|l|}{ A. crasna } \\
\hline Control & $4 a^{*}$ & $20.90 \mathrm{a}$ & $2.90 \mathrm{a}$ & $0.68 \mathrm{a}$ & $1.06 \mathrm{a}$ & $0.33 \mathrm{a}$ & $0.13 \mathrm{a}$ & 70 \\
\hline Entrosphora sp. & $73 \mathrm{~b}$ & $46.14 \mathrm{c}$ & $5.40 \mathrm{c}$ & $12.58 \mathrm{~b}$ & $5.72 \mathrm{~b}$ & $3.82 \mathrm{~b}$ & $1.35 \mathrm{~b}$ & 100 \\
\hline Gigaspora decipiens & $63 \mathrm{~b}$ & $29.58 \mathrm{~b}$ & $4.10 \mathrm{~b}$ & $11.64 \mathrm{~b}$ & $7.36 \mathrm{~b}$ & $3.26 \mathrm{~b}$ & $1.56 \mathrm{~b}$ & 100 \\
\hline Glomus clarum & $78 \mathrm{~b}$ & $32.43 \mathrm{~b}$ & $4.40 \mathrm{~b}$ & $8.82 \mathrm{~b}$ & $4.30 \mathrm{~b}$ & $0.86 \mathrm{a}$ & $0.27 \mathrm{a}$ & 100 \\
\hline Glomus sp. ZEA & $78 \mathrm{~b}$ & $38.94 \mathrm{c}$ & $4.70 \mathrm{~b}$ & $9.92 \mathrm{~b}$ & $4.54 \mathrm{~b}$ & $2.99 \mathrm{~b}$ & $1.01 \mathrm{~b}$ & 87 \\
\hline Glomus sp. ACA & $59 \mathrm{~b}$ & $24.60 \mathrm{a}$ & $3.70 \mathrm{a}$ & $13.46 \mathrm{~b}$ & $6.94 \mathrm{~b}$ & $4.19 \mathrm{~b}$ & $1.52 \mathrm{~b}$ & 100 \\
\hline
\end{tabular}

Remarks: * values with the same letter are not significantly different $(\mathrm{P}<0.05)$

$\mathrm{N}$ and $\mathrm{P}$ concentrations in shoot of $A$. malaccensis were higher in AM-colonized seedlings than that in control seedlings (Table 2) and there were differences in shoot $\mathrm{N}$ and $\mathrm{P}$ concentrations of $A$. malaccensis among five AM fungi. The AM colonization by Entrophospora sp., Gi. decipiens, G. clarum, Glomus sp. ZEA, and Glomus sp. ACA increased shoot N and P contents of $A$. malaccensis. A. malaccensis inoculated with five AM fungi was difference in shoot $\mathrm{N}$ and $\mathrm{P}$ contents. The $\mathrm{N}$ and $\mathrm{P}$ concentrations were significantly different in shoots of A. crasna seedling inoculated with Entrophospora sp, G. clarum, Glomus sp., ZEA and Glomus sp. ACA from those of control seedlings (Table 2), except $\mathrm{N}$ concentrations of A.crasna inoculated with $G i$. decipiens were not different from control seedlings. There were differences in shoot $\mathrm{N}$ and $\mathrm{P}$ contents of $A$. crasna among five $\mathrm{AM}$ fungi. 
Table 2. Nutrient concentrations and contents of $A$. malaccensis and $A$. crasna inoculated with or without AM fungi under greenhouse conditions

\begin{tabular}{|c|c|c|c|c|}
\hline Treatment & $\begin{array}{c}\text { N concentrations } \\
(\mathrm{mg} / \mathrm{g})\end{array}$ & $\begin{array}{l}\text { N contents } \\
\text { (mg/plant) }\end{array}$ & $\begin{array}{c}\text { P concentrations } \\
(\mathrm{mg} / \mathrm{g})\end{array}$ & $\begin{array}{l}\text { P contents } \\
\text { (mg/plant) }\end{array}$ \\
\hline \multicolumn{5}{|l|}{ A. malaccensis } \\
\hline Control & $8.6 \pm 0.2 \mathrm{a}$ & $3.49 \pm 0.5 \mathrm{a}$ & $0.65 \pm 0.02 \mathrm{a}$ & $0.26 \pm 0.04 \mathrm{a}$ \\
\hline Entrosphora sp. & $12.1 \pm 0.1 \mathrm{~d}$ & $17.28 \pm 2.09 \mathrm{c}$ & $0.73 \pm 0.01 \mathrm{~b}$ & $1.06 \pm 0.15 \mathrm{~b}$ \\
\hline \multicolumn{5}{|l|}{ Gigaspora } \\
\hline decipiens & $10.7 \pm 0.1 \mathrm{c}$ & $9.02 \pm 0.7 \mathrm{~b}$ & $0.85 \pm 0.01 \mathrm{c}$ & $0.75 \pm 0.07 \mathrm{~b}$ \\
\hline Glomus clarum & $10.4 \pm 0.1 \mathrm{~b}$ & $20.5 \pm 3.3 c$ & $0.72 \pm 0.02 \mathrm{~b}$ & $1.60 \pm 0.20 \mathrm{c}$ \\
\hline Glomus sp. ZEA & $11.1 \pm 0.2 \mathrm{c}$ & $8.8 \pm 0.9 \mathrm{~b}$ & $0.77 \pm 0.03 \mathrm{~b}$ & $0.60 \pm 0.07 \mathrm{~b}$ \\
\hline Glomus sp. ACA & $10.9 \pm 0.2 \mathrm{c}$ & $9.7 \pm 1.8 \mathrm{~b}$ & $1.04 \pm 0.03 \mathrm{~d}$ & $0.92 \pm 0.17 \mathrm{~b}$ \\
\hline \multicolumn{5}{|l|}{ A. crasna } \\
\hline Control & $7.9 \pm 0.1 \mathrm{a}^{*}$ & $2.6 \pm 0.6 \mathrm{a}$ & $0.78 \pm 0.02 \mathrm{a}$ & $0.26 \pm 0.06 \mathrm{a}$ \\
\hline $\begin{array}{l}\text { Entrosphora sp. } \\
\text { Gigaspora }\end{array}$ & $9.8 \pm 0.1 \mathrm{c}$ & $37.7 \pm 4.3 \mathrm{~d}$ & $1.42 \pm 0.03 \mathrm{e}$ & $5.40 \pm 0.60 \mathrm{c}$ \\
\hline decipiens & $8.2 \pm 0.2 \mathrm{a}$ & $26.7 \pm 4.1 \mathrm{c}$ & $0.85 \pm 0.02 \mathrm{~b}$ & $2.80 \pm 0.50 \mathrm{~b}$ \\
\hline Glomus clarum & $8.7 \pm 0.2 b$ & $7.46 \pm 1.05 \mathrm{~b}$ & $0.95 \pm 0.02 \mathrm{c}$ & $0.82 \pm 0.14 \mathrm{~b}$ \\
\hline Glomus sp. ZEA & $8.7 \pm 0.1 b$ & $25.87 \pm 3.67 \mathrm{c}$ & $0.96 \pm 0.03 \mathrm{c}$ & $2.85 \pm 0.41 \mathrm{~b}$ \\
\hline Glomus sp. ACA & $10.8 \pm 0.2 \mathrm{~d}$ & $45.9 \pm 9.6 \mathrm{e}$ & $1.22 \pm 0.02 \mathrm{~d}$ & $5.14 \pm 1.00 \mathrm{c}$ \\
\hline
\end{tabular}

Remarks: * values with the same letter are not significantly different $(P<0.05)$

Almost all parameters of plant growth of Aquilaria species were correlated with $\mathrm{N}$ and $\mathrm{P}$ content. Total fresh weight and dry weight of $A$. malaccensis or $A$. crasna were significantly correlated with $\mathrm{N}$ and $\mathrm{P}$ content (Table 3 and Table 4). Stem diameter of $A$. malaccensis or $A$. crasna was not significantly correlated with $\mathrm{N}$ and $\mathrm{P}$ contents. Only shoot height of $A$. malaccensis or $A$. crasna has significant relationship $(\mathrm{P}<0.05)$ with $\mathrm{P}$ content and $\mathrm{N}$ content. Correlation analyses revealed a positive relationship between shoot dry weight of A. malaccensis or A. crasna and $\mathrm{N}$ content (Figure 1). Similarly, $\mathrm{P}$ content was positively correlated with shoot dry weight of $A$. malaccensis or $A$. crasna (Figure 2).

Table 3. Correlation coefficient ( $r$ ) between shoot growth and nutrient content of $A$. malaccensis seedlings inoculated with or without AM fungi

\begin{tabular}{lcccccc}
\hline Parameter & Height & Stem diameter & Fresh weight & Dry weight & N content & P content \\
\hline Height & & $* * *$ & $* * *$ & NS & $*$ & NS \\
Stem diameter & $* * *$ & & $* * *$ & NS & NS & NS \\
fresh weight & $* * *$ & $* * *$ & & NS & $*$ & $*$ \\
Dry weight & NS & NS & NS & & $* * *$ & $* * *$ \\
N content & $*$ & NS & $*$ & $* * *$ & & $* * *$ \\
P content & NS & NS & $*$ & $* * *$ & $* * *$ & \\
\hline
\end{tabular}

Remarks: ***: $\mathrm{P}<0.001$

** : $\mathrm{P}<0.01$

* : $\mathrm{P}<0.05$

NS : non -significant 
Table 4. Correlation coefficient (r) between shoot growth and nutrient content of $A$. crasna seedlings inoculated with or without AM fungi

\begin{tabular}{lcccccc}
\hline Parameter & Height & Stem diameter & Fresh weight & Dry weight & N content & P content \\
\hline Height & & $* * *$ & $*$ & NS & NS & $*$ \\
Stem diameter & $* * *$ & & $*$ & NS & NS & NS \\
fresh weight & $*$ & $*$ & & $* * *$ & $* * *$ & $* * *$ \\
Dry weight & NS & NS & $* * *$ & & $* * *$ & $* * *$ \\
N content & NS & NS & $* * *$ & $* * *$ & & $* * *$ \\
P content & $*$ & NS & $* * *$ & $* * *$ & $* * *$ & \\
\hline
\end{tabular}

Remarks: ***: $\mathrm{P}<0.001$

$* *: \mathrm{P}<0.01$
$*: \mathrm{P}<0.05$

NS : non - significant

Table 5. Mycorrhizal dependency values (Plenchette et al., 1983) calculated from shoot dry weights of 6-month-old seedlings of Aquilaria species, inoculated or not with five different AM fungi

\begin{tabular}{lcccccc}
\hline \multirow{2}{*}{ Aquilaria species } & & \multicolumn{5}{c}{ Mycorrhizal Dependency (MD, \%) } \\
\cline { 2 - 6 } & Control & Entrophospora sp. & Gi. decipiens & G. clarum & Glomus sp.ZEA & Glomus sp.ACA \\
\hline A. malaccensis & - & 72 & 54 & 79 & 49 & 55 \\
A. crasna & - & 91 & 89 & 62 & 89 & 92 \\
\hline
\end{tabular}

\section{B. Mycorrhizal Dependency (MD)}

For a given fungus, MD values varied depending on the host species (Table 5). MD values obtained in this study with Aquilaria exceeded $55 \%$. The MD of A. malaccensis and A. crasna ranged from 49 to $79 \%$ and from 62 to $92 \%$, respectively. $A$. crasna had the highest MD values.

\section{Plant Growth and Survival Rate}

The AM colonization by five AM fungi increased shoot height of A. malaccensis (Table 1). Entrophospora sp., Gi. decipiens, G. clarum, Glomus sp. ZEA, and Glomus sp. ACA also increased the stem diameter of $A$. malaccensis. In addition, inoculation with five AM fungi increased shoot fresh weight, root fresh weight, shoot dry weight, and root dry weight of $A$. malaccensis. There were differences in plant growth among $A$. malaccensis seedlings inoculated with five AM fungi. The AM colonization by Entrophospora sp., Gi. decipiens, G. clarum, Glomus $s p$. ZEA increased shoot height and stem diameter of $A$. crasna at 6 months after transplantation (Table 1). Furthermore, inoculation of Entrophospora sp., Gi. decipiens, G. clarum, Glomus sp. ZEA and Glomus sp. ACA increased shoot fresh weight, root fresh weight, shoot dry weight and root dry weight. There were differences in plant growth among $A$. crasna seedlings inoculated with five AM fungi. The AM colonization by Glomus sp. ACA did not increase the shoot height and the stem diameter of $A$. crasna.

The AM colonization by Entrophospora sp., Gi. decipiens, G. clarum, Glomus sp. ZEA, and Glomus sp. ACA increased the survival rates of $A$. malaccensis at 6 months after transplantation under greenhouse conditions (Table 1 ). The survival rates of $A$. crasna inoculated with five AM fungi were also higher than those of $A$. crasna with control. 


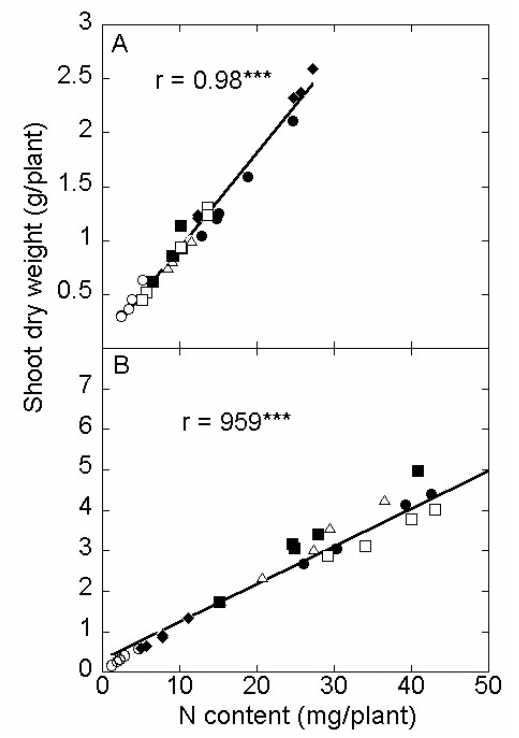

Fig 1. Correlation between shoot $\mathrm{N}$ content and shoot dry weight of $A$. malaccensis (A) and $A$. crasna (B) inoculated with or without AM fungi under greenhouse conditions. ( $\bigcirc$ ) Control; Entrophospora sp.; ( Gi. decipiens; ( G. clarum; $(\triangle)$ Glomus sp. ZEA; $(\square)$ Glomus sp. ACA. ***: $P<0.001$; **: $P$ $<0.01 ; *: P<0.05$; ns : non-significant.

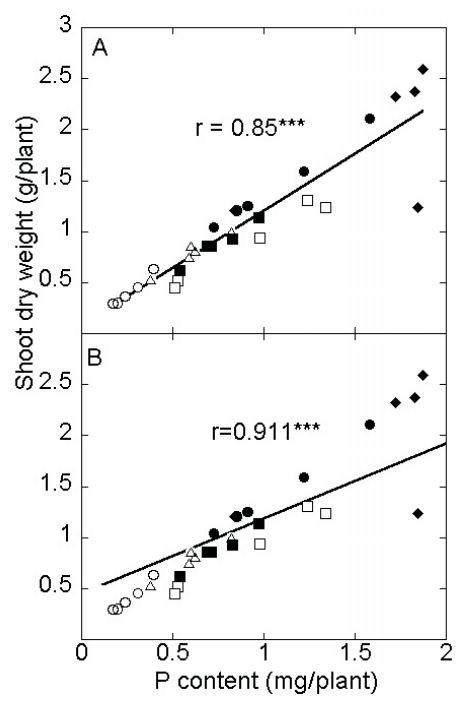

Fig 2. Correlation between shoot $\mathrm{P}$ content and shoot dry weight of $A$. malaccensis (A) and A. crasna (B) inoculated with or without AM fungi under greenhouse conditions. (○) Control; ( ) Entrophospora sp.; Gi. decipiens; $(\diamond)$ G. clarum; $(\triangle)$ Glomus sp. ZEA; $(\square)$ Glomus sp. ACA. ***: $P<$ 0.001 ; **: $P<0.01$; * $P<0.05$; ns : nonsignificant.

The present study shows the importance of AM fungi for the early growth and mineral nutrition of three species of gaharu woods. It demonstrates for the first time the effect of AM fungi on $A$. malaccensis and A. crasna seedlings under greenhouse conditions at 6 months after transplantation. Our results provide evidence that not only AM fungi improve plant growth and nutrient content, but also gaharu wood trees differ in their response when inoculated with selected AM fungi during the early growth. Our finding agrees with this previous study which showed that AM fungi increased early growth of 11 species of Eucalyptus. (Adjoud etal., 1996), Sesbania aegyptiaca and S.grandiflora (Giri and Mukerji, 2004).

Shoot $\mathrm{N}$ or P concentration of Aquilaria species were more higher in the AM seedlings than in the control ones, demonstrating that in the absence of AM associations, Aquilaria species were not capable to harvest enough $\mathrm{N}$ or $\mathrm{P}$ from the soil and keep adequate levels in their tissues, despite the major reduction in plant growth. The level of AM effectiveness of all the plant-fungus combination examined was also influenced by functional compatibility, measured as P concentrations. The P concentration had the most consistent effect on shoot biomass production in tropical fruit trees (Guissou et al., 1998). This has already been welldocumented in studies on other mycotrophic plants production in fruit trees. Guissou et al. (1998) observed that Parkia biglobosa, Tamarindus indica and Zizyphus mauritiana responded to 
three isolate of Acaulospora spinosa, Glomus aggregatum and G. manihotis better than to G. mosseae and $G$. intraradices. They suggested that enhanced $\mathrm{P}$ nutrition is the most likely cause of an increase in yield of these fruit tree seedlings.

Studies on Aquilaria species and other tropical tree species (Muthukumar et al., 2001) show that inoculation with AM fungi can reduce fertilizer requirement in plant production during nursery stage. Although such a benefit cost ratio was not tested in this study, the results undoubtedly indicate that AM inoculations can substantially reduce chemical fertilizer requirement in Aquilaria species seedling stocks production. Whatever may be the mechanism of action, inoculation with AM fungi, helps the early growth of Aquilaria species in acid soils having suboptimal AM fungi populations, regardless of the presence of native symbionts.

Mycorrhizal dependency (MD) in acid soil was higher in $A$. crasna than that in $A$. malaccensis. Based on these data, we propose a ranking of Aquilaria species according to the MD categories defined by Habte and Manajunath (1991) : A. crasna were considered very highly dependent (MD > 75\%) and $A$. malaccensis were highly dependent (25-50\% MD). The $\mathrm{MD}$ is frequently related to the morphological properties of the root of different plant species and also root systems with only a few, short root hairs are indicative of a high MD of the plant species concerned (Baylis, 1970). However, these Aquilaria species had a considerable degree of dependence on Entrophospora sp., Gi. decipiens, Glomus sp. ACA, G. clarum, and Glomus sp. ZEA. A similar effectiveness of AM fungi for different plant species was reported by Adjoud et al. (1996) and Guissou et al. (1998). The growth of A. crasna is faster than that of $A$. malaccensis at 6 months after transplantation under greenhouse conditions. The AM Entrophospora sp. colonization showed higher compatibility for association with $A$. crasna. In addition, $A$. crasna seeds had the highest probability of germination success $(92 \%)$ whereas those of $A$. malaccensis, $A$. microcarpa and $A$. filaria had the lowest (53\%) (Soehartono and Newton, 2001b).

The survival rate of Aquilaria species seedlings is a criteria of success in reforestation programs. These results also have a number implication for management of Aquilaria species population. Aquilaria species may be mix planted in Hevea brassiliensis (rubber tree) plantation and Elaeis guineensis (oil palm) plantation with agroforestry system for accelerating the population because these estate crops have a wide spacing $(6 \times 6 \mathrm{~m}$ or $7 \times 7 \mathrm{~m})$. Alternatively, Aquilaria species may be planted in the border of each block of estate crops, because Aquilaria spp. are shade tolerant in the young seedling stage (Ding Hou, 1960). The estate crop company or farmers may get profit and help promoting nature conservation in the context of the CITES listing of Aquilaria spp.

\section{CONCLUSION AND SUGGESTION}

It can be concluded that colonization by Entrophospora sp, Gi. decipiens, G. clarum, Glomus sp. ZEA and Glomus sp. ACA increased $\mathrm{N}$ and P content, plant growth and survival rates of $A$. malaccensis and $A$. crasna seedlings at 6 months after transplantation under greenhouse conditions. Entrophospora sp. showed higher compatibility for symbiosis with its host than $G i$. decipiens, G. clarum, Glomus sp. ZEA and Glomus sp. ACA. Entrophospora sp. was more effective in improving nutrient content and plant growth of Aquilaria species than Gi. decipiens, $G$. clarum, Glomus sp. ZEA and Glomus sp. ACA. Entrophospora sp might be the best choice if these 
Aquilaria species are selected for reforestation programmes. When Aquilaria seedlings are being grown in nurseries, the cultivation methods and the degree of AM symbiosis can affect post-planting success, particularly when the seedlings are destined for degraded lands or regeneration of tropical forest. Therefore, it is suggested Aquilaria should be adapted to Plimited environments, mainly when it is inoculated with specific AM fungi. In addition, AM fungi can help early growth of Aquilaria species and establish seedling stocks production in nursery scale.

\section{REFERENCES}

Adjoud D., C. Plenchette, R. Halli-Hargas and F. Lapeyrie. 1996. Response of 11 eucalyptus species to inoculation with three arbuscular mycorrhizal fungi. Mycorrhiza 6: 129135.

Baylis, G.T.S. 1970. Root hairs and phycomycetous mycorrhizas in phosphorus-deficient soil. Plant Soil 33: 713716.

Béreau M, T.S. Barigah, E. Louisanna and J. Garbaye. 2000. Effects of endomycorrhizal development and light regimes on the growth of Dicorynia guianensis Amshoff seedlings. Ann For Sci 57: 725-733.

Brundrett M, N. Bougher, B. Dell, T. Grove and N. Malajczuk. 1996. Working with mycorrhizas in Forestry and Agriculture. ACIAR Monograph 32, Canberra.

CITES. 2005. Convention on International Trade in Endangered Species of Wild Fauna and Flora. Appendices I, II and III of CITES. UNEP. 48 pp.

Ding Hou. 1960. Thymelaeaceae. In: C.G.G.J. Van Steenis (ed), Flora Malesiana, Series I, Vol. 6, Wolters-Noordhoff, Groningen, The Netherlands, pp. 1-15.

Giri B. and K.G. Mukerji KG. 2004. Mycorrhizal inoculant alleviates salt stress in Sesbania aegyptiaca and Sesbania grandiflora under field conditions: evidence for reduced sodium and improved magnesium uptake. Mycorrhiza 14: 307-312.

Guisso T, A.M. Bâ, J-M. Ouadba, S. Guinko and R. Duponnois. 1998. Responses of Parkia biglobosa (Jacq.) Benth, Tamarindus indica L. and Zizyphus mauritiana Lam. to arbuscular mycorrhizal fungi in a phosphorus-deficient sandy soil. Biol Fertil Soils 26: 194-198.

Habte M. and A. Manajunath. 1991. Categories of vesicular-arbuscular mycorrhizal dependency of host species. Mycorrhiza 1:3-12.

Haselwandter K. and G.D. Bowen. 1996. Mycorrhizal relations in tree for agroforestry and land rehabilitation. For Ecol Manage 81:1-17.

McGonigle T.P., M.H. Miller, D.G. Evans, G.L. Fairchild and J.A. Swan. 1990. A new method which gives an objective measure of colonization of roots by vesicular-arbuscular mycorrhizal fungi. New Phytol 115: 495-501. 
Muthukumar T, K. Udaiyan and V. Rajeshkannan. 2001. Response of neem (Azadirachta indica A. Juss) to indigenous arbuscular mycorrhizal fungi, phosphate-solubilizing and asymbiotic nitrogen-fixing bacteria under tropical nursery conditions. Biol Fertil Soils 34: 417-426.

Olsen S.R. and L.E. Sommers. 1982. Phosphorus. In: A.L. Page (ed), Methods of soil analysis, Part 2 Chemical and microbiological properties, American Society of Agronomy, Madison, p 403-430.

Paoli G.D., D.R. Peart, M. Leighton and I. Samsoedin. 2001. An ecological and economic assessment of the nontimber forest product gaharu wood in Gunung Palung National Park, West Kalimantan, Indonesia. Conservation Biology 15: 1721-1732.

Plenchette C., J.A.Fortin, and V. Furlan. 1983. Growth responses of several plant species to mycorrhizae in a soil of moderate P-fertility. I. Mycorrhizal dependency under field conditions. Plant Soil 70: 199209

Soehartono T. and A.C. Newton. 2001a. Conservation and sustainable use of tropical trees in the genus Aquilaria II. Status and distribution in Indonesia. Biol Conservation 96: 8394.

Soehartono T. and A.C. Newton. 2001b. Reproductive ecology of Aquilaria spp. in Indonesia. For Ecol Manage 152: 59-71.

Tawaraya K., Y. Takaya, M. Turjaman, S.J. Tuah, S.H. Limin, Y. Tamai, J.Y. Cha, T. Wagatsuma and M. Osaki. 2003. Arbuscular mycorrhizal colonization of tree species grown in peat swamp forests of Central Kalimantan, Indonesia. For Ecol Manage 182: 381386.

Zandavalli R.B., L.R. Dillenburg, P.V.D. de Souza. 2004. Growth responses of Araucaria angustifolia (Araucariaceae) to inoculation with the mycorrhizal fungus Glomus clarum. App Soil Ecol 25:245-255. 